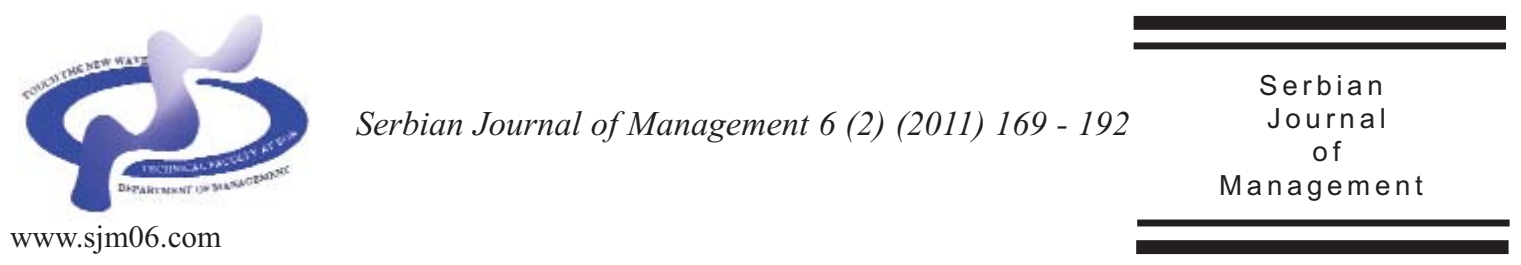

\title{
ECO RISK MANAGEMENT IN MINING, ECO PRACTICUM
}

\author{
Slobodan Radosavljević $\mathbf{a}^{*}$ and Milan Radosavljevićb \\ $a_{R B}$ "Kolubara", Lazarevac, Svetog Save 1, Lazarevac, Serbia \\ $b_{G O}$ Lazarevac, Karađorđeva 42., Lazarevac, Serbia
}

(Received 21 September 2010; accepted 3 January 2011)

\begin{abstract}
Environmental protection is a key factor for sustainable development in the area of exploitation of natural energy resources. Solving problems in this field requires a quality strategic positioning eco exploitation sites, which is the most burdened by environmental problems, based on modern scientific approaches and definitions. Realistically frequent criticism and environmental hazards in mining the potential of various statements. There is a long-term disruption of natural flow and overall ecological balance of the system. Demonstrated environmental destruction and damage of smaller or larger extent the result, which can be accessed from the aspect of taking corrective action by the state. A complex analysis of the causes, the analysis of environmental risks and the definition of preventive environmental strategy, hardly can speak, at least in the forms of modern analytical and methodological approaches. The basis of determining the initiation of interest on taking responsibility for local environmental priorities and their protection in areas of intensive exploitation of works. It is a negative impact on human health and the need to preserve the total ecosystem. Analysis of environmental risks is becoming logistically purpose and need with which to be flexible, adaptable, and efficiently organize and manage access to environmental reality and truth in the context of improvements, now and in the near future. This paper presents real experiences and research results in environmental practicum proposals and implementation of modern concepts, methods and models for the analysis of environmental risks.
\end{abstract}

Keywords: environmental risk, eco practical, eco-destruction, model, mining

\section{INTRODUCTION}

Create an eco-strategy of environmental protection at sites of urban municipalities to promote the new position of environmental quality in an advance, the total development potential. The nature of society, globalization and the current world economic crisis,

\footnotetext{
* Corresponding author:drslobodanr@gmail.com
}

DOI: 10.5937/sjm1102169R 
determine the life and fate of the local. This is explicitly the need to initiate a different eco-thinking where to generate new ideas in the context of new environmental approaches, communication flows and patterns as well as partial or complete reengineering eco extensions, (Asif, et al., 2009). Eco-system change, organizational eco models with the inclusion of all subjects of eco-systems and new organizational behavior at the local level, at this point become an imperative. For thousands of years the man and nature harmoniously developed and prospered. Nature has helped man to survive and was very tolerant towards him. The balance is there until the middle of the twentieth century, (Afrazeh \& Bartsch, 2007). Realistically fast development of science and technology, the race for profit, caused the human non-sustainable, where aggressiveness is the nature of almost forgotten. Since it has already taken over half a century before it is returned, the pace of that nature simply cannot stand. Nature itself reminds us of this through a variety of phenomena, such as the greenhouse effect, acid rain, continuous reduction of the ozone layer, uncontrolled deforestation, growth of hazardous waste, urban chaos, water pollution, soil, climate change, extinction of many animal and plant species and more, (Bernardo et al., (2009). These are just some of numerous problems that are generated between man and nature-that are current at the local level.

Degradation sites and "Kolubara" Lazarevac long as the exploitation of resources that modther nature gave selflessly to this end, primarily coal.

Eco experts agree that there are realistic opportunities to generate and promote new values: health, knowledge, freedom, quality, communications, environment and others,
(Bernardo et al., 2010). However, the form of deeply rooted attitudes towards nature is still prevents the establishment of a new logic of life and eco-cultural work on the local level. Considering the large volume of degrading that causes increasingly common at-risk, emergency, accidents at local events, required the development and implementation of new methods, techniques and instruments for analysis, reduction, monitoring and managing environmental risk, (Griffith \& Bhutto, 2008; Mihajlović, et al., 2010). The appearance and development of special events are caused by sudden, unpredictable and unexpected circumstances of high risk, and often can not be analyzed and addressed on the basis of past experience. Today the necessary analysis and reduction of environmental risk, on the basis of scientific knowledge while constantly developing new approaches strategies and plans. Environmental Mission in local means establishing harmony between man and nature through a total redesign of the existing system of values and ethics awareness and reshaping the new eco form and content, (Dependability management-Part 3., 1995).

The traditional concept of development, focused on the production of material goods and aggressive exploitation of natural resources over to get closer to the end, (Law on the Protection of Environment, 2004). A further incentive in that context becomes irrelevant, which allows use smaller and the consequences of degrading nature of growing. Awareness of environmental problems at local level is often much faster applications registered in the informal statement, but it is through eco establishes scientific knowledge, (Report of the World Bank-Serbia and Montenegro, 2003). The result is the existence of a sufficiently comprehensive strategy and environmental 
policy at the local level. Thus, the expansion of the science of quality, long time took charge of the environmental components as well as parameters of eco products, (IS CEI 300-3-9. Part 3. Dependability management Application guide-Section 9, 1995). However, more and more the existence of all subjects at the local level depends on their willingness to comply with the projected environmental measures and regulations. Eco-system of the local need to address the issue of tasks, actors, structure, organization, management and IT support, as well as to develop the basic parameters and response procedures at all levels.

The next steps are:

- establishment of a functional ecological relationships and communication,

- environmental monitoring and,

- environment management with logistical support.

It turns out that the basic task of achieving high quality eco future for generations to come. Opportunities for environmental protection in terms of degrading grow in line with the development of environmental knowledge, awareness and responsibility, (ISO 31000. 2009). New and modern technology on the other hand, discover new possibilities of application of environmental management. In consideration of future developments in the field of environment, there is no one way to meet a future that is not included in the analysis, reduction, monitoring and management of risk. Eco instruments, measures, metrics, monitoring and controlling must have a decisive role, (Karapetrovic, 2002).

It turns out that the right to protect the natural environment, personal and inalienable right of man. As such, it is related to his life and health-as the most human and civilizational values. In accordance with current legislation and the positive experiences from the closer and further to the local environment requires special attention paid to more timely, accountable and constantly reporting to the public on the actual ecological truth, (Karapetrovic \& Casadesús, 2009). Staffing resource to local environmental resources must play a crucial role in the operationalization of environmental strategies, information and education in all subjects ecosystems. In addition to professional staff with a high level of competence, to solve environmental problems at the local level, it is necessary and good long-term financial logistics, (Environmental quality of the city of Belgrade in 2005).

\section{POTENTIAL ECO DESTRUCTION IN MINING AND RISK}

Environmental problems identified through the environmental aspects that generated criticism and destruction in the mining, the analysis can be displayed in the context of the current situation:

- air quality in the monitored area (industry as a source of air pollution, traffic as a source of air pollution, fire place as a source of pollution),

- water quality in the monitored area (quality of water supply, quality of municipal wastewater, industrial waste water quality),

- impact of waste on the environment, (as municipal solid waste, landfill waste status of local, wild-state illegal dumpsites, the state of industrial waste, hazardous industrial waste, medical waste),

- soil quality in the local (state capture and degradation of land due to local mining, pollution of soil, (plant foods of animal origin), waste from energy plant industrial 
complex, the use of land for agricultural purposes, mudslides, landslides and erosion),

- the preservation of biodiversity,

- allowable noise levels at the local level,

- insufficient environmental awareness,

- the quality of environmental strategies, environmental plans and all documents as a very important instrument for the protection and improvement of the environment at local level.

Analysis of real ecological point of view opens a number of questions regarding the application of potential criticism and destructive statements, which can still be de composed viewed in the context of negative environmental synergies, partially and jointly with other important aspects, (Main, 2005). The specified definition refers to a real complicated and complex procedure of risk analysis of environmental and choice of analytical and methodological approaches in this context, (Michael \& Launa, 2003).

2.1. The aim of the research and environmental hypotheses

The process of research is carried out in the period 2002-2009 at the premises and immediate area and beyond micro-site environment and the exploitation of energy resource potential.

The aim of the research is oriented towards:

- development of methodology for the systematic analysis of environmental risks in mining,

- elaboration of the necessary criteria and processes that will help in assessing the risk to the system,

- elaboration of a methodology for assessing the impact of destructive potential environmental aspects of site operation,

- assessing the current situation and realistic framework for the required partial or total change in the context of improving the eco-system performance,

- defining the necessary conditions for the management and monitoring of environmental risk.

The study defined the following hypothesis:

- it is possible to realize the strategy of systematic analysis of environmental risks in the mining process,

- it is possible to determine the likelihood of ecological and eco-critical parts of the destructive potential of the process and the system as a whole,

- it is possible to use contemporary models and methods for the analysis, evaluation, reduction, monitoring and management of environmental risk,

- it is possible that at the stage of environmental monitoring to detect adverse environmental effects and preventive measures to construct solutions to the critical situation,

- it is possible to design a model for quality management and monitoring of environmental risk in the mining industry.

\subsection{Research the current situation}

So far, the development of technological processes in mining has contributed significantly to the economic development area micro location exploitation. However, a large volume of mining, associated with the production of electricity has caused a number of negative changes in the environment area, with particular influence on the location of the macro environment. In addition, a significant impact on the environment are: industry, the functions of settlements, transport and agriculture. Area of land occupied by mining works on the 
researched area in early 2008 amounted to about 860 ha, of which the active zone mines about 29 ha, and in the neighboring locality of about 27 ha. In addition to mines, the sources of environmental impacts are related activities (assembly, machinery), industrial railways, road infrastructure and the adjacent settlements. Also, i had to take into account the impact of the current dig, located along the northern border areas and the impact of industrial plants for processing coal.

The paper is a review only of information obtained in the survey took place.

\subsubsection{Air quality}

To air pollution in surface coal mining comes in, transportation and reloading of coal and overburden. Especially important pollutants (especiallyduring strong winds) may be dumping waste in the dryperiod. When working machinery driven by internal motorscombustion, harmful gases are emitted as nitric oxide (NO), carbonmonoxide (CO), sulfur dioxide (SO2), also the soot and dust particles.Air quality in the area of micro-locations exploitation regularly controlled. Results of measuring concentration. "Classical" pollutants materials were as follows:

- Soot: Increased concentrations were recorded in the winter months (October to February). Middle monthly soot concentrations ranging from 3.4 to 25.4 $\mu \mathrm{g} / \mathrm{m} 3$. The average annual concentration was $11.5 \mu \mathrm{g} / \mathrm{m} 3$ (which exceeds the 50 $\mu \mathrm{g} / \mathrm{m} 3 \mathrm{GVI}$ ), and recorded a total of GVI excess of 9 days (from December to January);

- Suspended particles: Increasing concentrations (CSR) have been determined in the winter months (from December to March). Middle monthly concentrations ranging from 55.8 to $170.8 \mu \mathrm{g} / \mathrm{m} 3$, and the average annual concentration amounted to $98.6 \mu \mathrm{g} / \mathrm{m} 3$ (which GVI exceeds $70 \mu \mathrm{g} / \mathrm{m} 3$ );

- Sedimentary matter: The highest concentrations are in the spring months, at least during the summer months. Middle monthly concentrations ranging from 71.9 to $268.1 \mu \mathrm{g} / \mathrm{m} 3$ dan, while the mean annual concentration of total taložnih matteramounted to $164.0 \mu \mathrm{g} / \mathrm{m} 3 \mathrm{dan}$;

- $\quad$ Sulfur dioxide (SO2): concentrations were higher in winter months, high monthly concentrations ranging from $<5.0$ to 9.2 $\mu \mathrm{g} / \mathrm{m} 3$, while the mean annual amounted to $6.2 \mu \mathrm{g} / \mathrm{m} 3$, and not exceeding a single day;

- Azotdioksida (NO2): The concentrations were higher in winter months. Medium monthly concentrations ranging from 6.5 to $13.0 \mu \mathrm{g} / \mathrm{m} 3$, while the mean annual amounted to $9.2 \mu \mathrm{g} / \mathrm{m} 3$, and not exceeding a single day of the year.

In previous measurements of suspended matter and concluded taložnih the presence of heavy metals: nickel, chromium, cadmium, manganese, lead and others.Values concentration of nickel, chromium and manganese occasionally exceed MDK.

\subsubsection{Water quality}

Exploitation of coal by surface characteristics of the technological process causes changes in hydrogeological and hydrological regime of narrow and wide area exploitation as well as emissions into surface and ground water. We should bear in mind the risk of oily water caused by repair machinery (of oil, lubricants, etc.). In addition, the river and its tributaries flowing into the naseljske waste water without treatment.

The river is usually in the IV or IV/III- 
class quality, while in periods of little water even in a state of"out of class"when he practically turned into a collector of waste water. As a result, excess MDK especially pronounced: the organic matter (BOD5), NH4-N, the number of school formnih germ (NBK) and an unfavorable condition.

The values of suspended matter from time to time belonging to classes III and IV, as well as

increased content of dissolved oxygen, the percentage of oxygen saturation and decreased electrical conductivity. Of hazardous substances were registered higher concentrations dissolved manganese, phenols, iron, nickel. Sapri biological research quality water show that the stream of we ighted moderate organic pollution dominated by organisms indicators $\beta$ and $\alpha$ meso the test zone.

Measurement results of standard physicochemical parameters of waste water and the river upstream and downstream of waste water flows have shown that waste water does not impact significantly on the change of river water quality. Measurements in the month of March 2000., 2006. and 2008. showed that flows downstream from waste water comes to potentially water temperature by about $0,8^{\circ} \mathrm{C}$, an increase of suspended solids and phenols (when measuring 2007.).

Bacteriological examination showed that the total number of bacteria in 1 liter significantly increase downstream. Rivers have uneven water regimes, with the growth of short and long periods of little water. To obtain a more accurate impact assessment of waste water to the river should be used for measuring water in a small period of time. Especially when one bears in mind that the amount of water discharged into the river is $20-100 \%$ of its secondary flow. The river is extra demand on waste water from mines, which are tributaries of the creek in the area of settlement.

Analysis of the quality of raw water from source (measurement in October 2007.) Show that, in accordance with the Regulation on hygienic quality of drinking water, it comes to exceeding the following parameters: fuzziness, and the smell of ammonia. Apart from pollution,

surface mining activities (including ancillary drainage systems) groundwater disturb modes radical folding pijezo metric level, which threatens the use of underground water in water supply systems and individual wells.

At the area considered a major problem is under-built sewer network. Rural settlements are sanitary Unordered or no sewerage system for waste water. Evacuation of waste water in households the largest percentage done by septic tanks.

\subsubsection{Soil quality}

Almost all areas of forest are planted in the period 1973-1993. The built in forest reclamation of overburden dumps. In forest stands that are built on depository salts, most frequent are pure cultures of red pine and white pine, followed by a mixed culture of conifers. Places the happiness and pure culture of wood: oak, maple, ash and others.

Data on soil pollution in the area are scarce. Based on the available analysis of the impact of certain mines and industrial facilities can be concluded that the greatest pollution coming out of the soil near the source of contamination (250-500 meters), due to direct contamination of harmful particles, waste water and harmful gases. Secondary contamination is caused by the transport and distribution of particle matter. 


\subsubsection{Noise and Vibration}

Possibility of adverse impacts of excessive noise and vibration in the working environment exists in all phases of the operation of surface mines.

Noise sources are mining coal mining machinery, transportation and ancillary works, railway network to transport coal and road transport. Estimates of noise level forreceptor distance $500 \mathrm{~m}$ from the surface mines have shown that noise levels do not exceed the allowable value. At a distance $300-500 \mathrm{~m}$ from the mine noise levels may be higher than $55 \mathrm{~dB}(\mathrm{~A})$, depending on the current layout of equipment on mine.

\subsubsection{Solid Waste Management}

In the area of micro-locations exploitation handling waste is not solved in a satisfactory manner. Organized collection is performed in the territory Baroševca, Medoševca and Špića, while in the territory of the settlement Burovo Zeoke collection and partly organized. There are "wild" landfills, and dumps that affect soil and water pollution. On the territory of Baroševca, resulting in depression of coal mining fields delaying the municipal solid waste Lazarevac, Lajkovac and Mionica. This landfill does not meet the minimum sanitary conditions planning and equipment.

\subsubsection{Identified environmental problems}

The main sources of environmental pollution extraction of lignite, coal and electricity and thermal energy in the Kolubara basin for many years have produced significant negative consequences in the environment, since they have not applied appropriate measures to protect the environment. The paper discussed the characteristics of the main sources of pollution and environmental degradation, it was determined the current situation and environmental problems in the area plan and the need for improvement of environmental quality.

In addition to the occupation and degradation of land, mining negative impact on air quality, groundwater and surface water, as well as an increase in noise level. The biggest negative impact of mining on the exercise mines where there is destruction of land, agricultural areas, wild flora and evictions wild animals from their habitat. Due to the depth of excavation possible significant impact the stability of the ground, if you do not take preventive measures. In the area of mines present a significant emission of dust during coal mining.

In addition to mining equipment and transport vehicles emit harmful gases such as nitrogen oxides (NOx), carbon monoxide $(\mathrm{CO})$, sulfur dioxide $\left(\mathrm{SO}_{2}\right)$ and volatile organic compounds (VOC), whose contribution to air pollution is high. The exploitation of lignite in open pits leads to significant changes in groundwater regime. Due to the overthrow of the level of underground water (necessary for the smooth coal mining), a large number of local springs and wells remains without water, which threatens the water supply of residents and reduce the production capacity of the surrounding land. Significant environmental problem and the emergence of atmospheric water mining, which solves the drainage systems. Because of mining machinery in the coal mining and washing, there is internal contamination of water mines and underground water.

The exploitation of these lignite causes direct negative consequences environment: 
- $\quad$ occupancy and destruction of fertile agricultural land,

- change of morphological, geological characteristics and pejsažnih areas,

- destruction of vegetation and natural habitats,

- changing trends and regimes of surface and ground water,

- increase the risk of floods and landslides;

- water pollution and soil waste water from mines, oilderivatives, faecal pollution, detergents,

- $\quad$ inadequate disposal of solid waste,

- air pollution from mines and dust smoke fumes from vehicles andboiler,

- increased noise and vibration,

- $\quad$ soil subsidence.

On the basis of the environment and the possible impact on the environment was conducted to identify significant environmental aspects according to the criteria given in"guide for the implementation of the strategic assessment of the impact on the environment", whose results are shown in (Table 1).

The criteria for assessment of environmental impacts in the study to determine the important aspects are:

- I - intensity,

- $\quad$ - the spatial scale,

- V - probability,

- $\mathrm{T}$ - duration,

- $\mathrm{K}$ - cumulative,

- $\mathrm{M}$ - protection.

Categories significant influence:

- $\quad \mathrm{Z}$ - negligible,

- $\quad \mathrm{M}$ - small,

- $\mathrm{S}$ - medium,

- V - a large,

- W - very big.

Environmental impacts of the category Znegligible and M-low, may be considered to be not significant because of the intensity or spatial scale, as well as other criteria. Based on the results of the preliminary estimates in the study omitted the following aspects of the environment: climate change, protected natural resources, traffic load, the intensity of vibration, heat load, ionizing and non ionizing radiation.

On the basis of estimates made, it can be concluded that the strategic impact assessment should consider the following potential significant impacts on the environment:

- air,

- water,

- land,

- flora and fauna,

- habitats and biodiversity,

- cultural property and monuments,

- public health,

- population and households,

- private and public buildings,

- water infrastructure,

- traffic infrastructure,

- industrial facilities,

- waste management system,

- noise level.

\subsubsection{General and specific objectives and eco selection of indicators}

The overall goal of environmental protection in the strategic impact assessment is defined as the prevention, reduction or compensation of the negative impacts of development areas on the environment and the overall socio-economic development.The specific objectives of environmental protection and sustainable exploitation of areas of micro-locations include:

- reduce the level of emissions into the air,

- reduce the level of population 
exposure to air pollution,

- ensure sustainable use of water,

- conserving modes of ground and surface water,

- to improve the quality of groundwater and surface water,

- $\quad$ to ensure the stability of the terrain on the edge of the pits,

- preservation of arable agricultural land,

- $\quad$ establish an area of forest land,

- avoid irreversible loss of flora and fauna,

- to preserve and enhance the landscape through reclamation,

- preservation of protected and monitoring and management.

Table 1. Identified important aspects of the destructive impact on the environment

\begin{tabular}{|c|c|c|c|c|c|c|c|c|c|c|c|c|}
\hline \multirow{2}{*}{\multicolumn{2}{|c|}{$\begin{array}{c}\text { Possible impacts on the } \\
\text { environmental aspects }\end{array}$}} & \multicolumn{6}{|c|}{$\begin{array}{l}\text { The criteria for assessing the } \\
\text { impact }\end{array}$} & \multicolumn{5}{|c|}{$\begin{array}{l}\text { The importance of } \\
\text { the impact }\end{array}$} \\
\hline & & $\mathrm{II}$ & $\mathrm{P}$ & $\mathrm{V}$ & $\mathrm{T}$ & $\mathrm{K}$ & $\bar{M}$ & $\mathrm{Z}$ & $\mathrm{M}$ & $\mathrm{S}$ & $\mathrm{V}$ & $\mathrm{W}$ \\
\hline 1 & Air & - & - & - & - & - & + & & & & & \\
\hline \multicolumn{2}{|c|}{\begin{tabular}{l|l}
2 & Water \\
\end{tabular}} & - & - & - & - & - & + & & & & & \\
\hline 3 & Land & - & - & - & - & - & + & & & & & \\
\hline 4 & Climate & 0 & 0 & 0 & 0 & 0 & 0 & & & & & \\
\hline 5 & Flora and fauna & - & - & - & - & 0 & + & & & & & \\
\hline 6 & Habitats and biodiversity & - & - & - & - & 0 & + & & & & & \\
\hline 7 & Protected natural resources & 0 & 0 & 0 & 0 & 0 & 0 & & & & & \\
\hline 8 & $\begin{array}{l}\text { Cultural property and } \\
\text { monuments }\end{array}$ & - & 0 & - & - & 0 & + & & & & & \\
\hline 9 & Public health & - & - & - & - & - & + & & & & & \\
\hline 10 & Population and households & - & - & - & - & - & + & & & & & \\
\hline 11 & Private and public buildings & - & - & - & - & - & + & & & & & \\
\hline 12 & Water infrastructure & - & - & - & - & - & + & & & & & \\
\hline 13 & Traffic infrastructure & - & - & - & - & - & + & & & & & \\
\hline 14 & Traffic load & - & - & - & - & - & 0 & & & & & \\
\hline 15 & Industrial facilities & - & - & - & - & 0 & + & & & & & \\
\hline 16 & Waste Management System & - & - & - & - & - & + & & & & & \\
\hline 17 & Noise Level & - & 0 & 0 & 0 & - & + & & & & & \\
\hline 18 & The intensity of vibration & - & 0 & 0 & 0 & - & + & & & & & \\
\hline 19 & Thermal load & 0 & 0 & 0 & 0 & 0 & 0 & & & & & \\
\hline 20 & Lonizing radiation & 0 & 0 & 0 & 0 & 0 & 0 & & & & & \\
\hline+ & \begin{tabular}{l|l} 
positive impact & -
\end{tabular} & \multicolumn{3}{|c|}{$\begin{array}{l}\text { negative } \\
\text { impact }\end{array}$} & 0 & \multicolumn{7}{|c|}{$\begin{array}{c}\text { has no influence or impact } \\
\text { unclear }\end{array}$} \\
\hline
\end{tabular}


Table 2.Display specific targets and indicators in the survey

\begin{tabular}{|c|c|c|}
\hline \multicolumn{2}{|r|}{ Specific environmental objectives } & Indicators \\
\hline 1 & -Reduce the level of emissions in the air & -Particulate emissions, $\mathrm{SO} 2$ and $\mathrm{NOx}$ \\
\hline \multirow{3}{*}{2} & \multirow{3}{*}{-Reduce the level of population exposure to air pollution } & $\begin{array}{l}\text {-Number of days with excess GVI for soot, } \mathrm{SO} 2, \\
\text { NOx and sedimentary matter }\end{array}$ \\
\hline & & -Indices of air quality \\
\hline & & -Number of households exposed to elevated air pollution \\
\hline \multirow{4}{*}{3} & \multirow{4}{*}{-Ensure sustainable use of water } & -The amount of water that spreads from underground water (m3/god) \\
\hline & & -The amount of water that covers the rivers (m3/god) \\
\hline & & -Water consumption (m3/st) \\
\hline & & -The amount of water that is recycled (\%) \\
\hline \multirow{2}{*}{4} & \multirow{2}{*}{-Modes to preserve groundwater and surface water } & -Reducing the level of underground water (m) \\
\hline & & -The minimum and average flow in rivers $(\mathrm{m} 3 / \mathrm{s})$ \\
\hline \multirow{2}{*}{5} & \multirow[t]{2}{*}{-To improve the quality of groundwater and surface water } & -Change the level of pollution of underground water (\%) \\
\hline & & -Change of quality classes of rivers (\%) \\
\hline 6 & -To ensure the stability of the terrain on the edge of the pits & -The size of the total subsidence ( $\mathrm{m} / 25$ years) \\
\hline 7 & -Preservation of arable agricultural land & -Change the area of arable land (\%) \\
\hline 8 & -To set up an area of forest land & -Change the area of forest land (\%) \\
\hline 9 & -Avoid irreversible loss of flora and fauna & $-\%$ Of lost species in the region \\
\hline 10 & -Preserve and enhance the landscape through reclamation & $-\mathrm{Il}=\%$ re cultured area $/ \%$ area under mining and landfill \\
\hline 11 & $\begin{array}{l}\text {-Preservation of protected and unprotected significant cultural } \\
\text { property }\end{array}$ & -The number and importance of endangered cultural heritage objects \\
\hline \multirow{2}{*}{12} & \multirow{2}{*}{$\begin{array}{l}\text {-Soften the negative impact of development on the } \\
\text { demographics }\end{array}$} & Population Change (\%) \\
\hline & & -The number of households moving (\%) \\
\hline \multirow{3}{*}{13} & \multirow{3}{*}{ Protect and improve public health } & -Life expectancy at birth \\
\hline & & -Frequency of respiratory diseases $(\%)$ \\
\hline & & $-\%$ Of the population exposed to elevated noise \\
\hline \multirow{2}{*}{14} & \multirow{2}{*}{-Minimize the impact of settlements and buildings } & -The number of facilities for destruction (\%) \\
\hline & & -The number of the transfer (\%) \\
\hline \multirow{2}{*}{15} & \multirow{2}{*}{-To encourage economic development and employment } & $-\%$ Of households with income above average \\
\hline & & -Number of employees (\%) \\
\hline 16 & -Minimize the impact on road network & -The length of the displaced roads $(\mathrm{km})$ \\
\hline 17 & -Minimize the impact on waterways & -The length of the displaced water flows $(\mathrm{km})$ \\
\hline \multirow{2}{*}{18} & \multirow{2}{*}{-To improve water supply } & $-\%$ Of households connected to water supply network \\
\hline & & -Number of hours per month without water \\
\hline \multirow{2}{*}{19} & \multirow{2}{*}{-To improve the treatment and disposal of solid waste } & $-\%$ Identified waste is recycled \\
\hline & & \% Lime waste is disposed to landfill \\
\hline 20 & -To promote eco-system monitoring and management & $\begin{array}{l}\text {-The number of development programs for the protection of the } \\
\text { environment, } \\
\text {-The number of measuring points in the system monitoring }\end{array}$ \\
\hline
\end{tabular}

\subsubsection{Analysis of possible effects and measures for reduction of eco destruction}

Variations impact assessment was carried out using the matrix in which the estimates of species and the importance of the impact of development scenarios for variations for each sector in relation to specific targets and indicators, strategic assessments.

The assessment was carried out qualitative method, in accordance with the adopted methodology, with three grades. 
Table 3.The adopted methodology in the study for evaluation of the three grades

\begin{tabular}{|c|c|c|c|c|c|}
\hline+ & $\begin{array}{c}\text { Positive } \\
\text { impact }\end{array}$ & - & $\begin{array}{c}\text { Negative } \\
\text { impact }\end{array}$ & 0 & $\begin{array}{c}\text { Has no } \\
\text { influence or } \\
\text { impact unclear }\end{array}$ \\
\hline
\end{tabular}

Table 4.Two-variant assessment of the impact on the environment surrounding the exploitation of micro-location

\begin{tabular}{|c|c|c|c|c|c|c|c|c|c|c|c|c|c|c|c|c|c|c|c|c|c|}
\hline \multirow[b]{2}{*}{ Sector } & \multirow{2}{*}{$\begin{array}{c}\text { Variety } \\
\text { development }\end{array}$} & \multicolumn{20}{|c|}{ The objectives of the strategic assessment } \\
\hline & & 1 & 2 & 3 & 4 & 5 & 6 & 7 & 8 & 9 & 10 & 11 & 12 & 13 & 14 & 15 & 16 & 17 & 18 & 19 & 20 \\
\hline \multirow{2}{*}{$\begin{array}{l}\text { Mining and } \\
\text { economic } \\
\text { development }\end{array}$} & "A" & - & - & - & - & - & 0 & - & 0 & 0 & - & 0 & 0 & 0 & 0 & - & 0 & 0 & 0 & - & - \\
\hline & "B" & - & 0 & + & 0 & 0 & 0 & - & + & 0 & 0 & + & 0 & + & 0 & + & - & - & + & + & + \\
\hline \multirow{2}{*}{$\begin{array}{c}\text { Population, public } \\
\text { services and housing }\end{array}$} & "A" & - & - & - & 0 & - & 0 & - & 0 & 0 & 0 & 0 & 0 & 0 & + & 0 & - & 0 & 0 & - & 0 \\
\hline & "B" & 0 & 0 & + & 0 & + & 0 & - & 0 & 0 & 0 & 0 & - & + & + & + & 0 & 0 & + & + & + \\
\hline \multirow{2}{*}{$\begin{array}{l}\text { Agriculture and } \\
\text { forestry }\end{array}$} & "A" & 0 & 0 & - & 0 & 0 & 0 & + & 0 & 0 & 0 & 0 & 0 & 0 & 0 & 0 & 0 & 0 & 0 & 0 & 0 \\
\hline & "B" & 0 & + & + & 0 & 0 & 0 & - & + & - & + & 0 & 0 & 0 & 0 & 0 & 0 & 0 & 0 & 0 & 0 \\
\hline \multirow{2}{*}{$\begin{array}{c}\text { Traffic } \\
\text { infrastructure }\end{array}$} & "A" & - & - & 0 & 0 & 0 & 0 & 0 & 0 & 0 & 0 & 0 & 0 & 0 & 0 & 0 & 0 & 0 & 0 & 0 & 0 \\
\hline & "B" & + & + & 0 & 0 & + & 0 & - & 0 & 0 & 0 & 0 & 0 & 0 & + & 0 & - & 0 & 0 & 0 & 0 \\
\hline \multirow{2}{*}{$\begin{array}{c}\text { Relocation of the river } \\
\text { and flood control }\end{array}$} & "A" & 0 & 0 & 0 & 0 & 0 & 0 & 0 & 0 & 0 & 0 & 0 & 0 & 0 & 0 & 0 & 0 & 0 & 0 & 0 & 0 \\
\hline & "B" & 0 & 0 & - & + & 0 & 0 & - & 0 & 0 & - & 0 & 0 & 0 & 0 & + & 0 & + & 0 & 0 & 0 \\
\hline \multirow{2}{*}{$\begin{array}{l}\text { Hydraulic } \\
\text { infrastructure }\end{array}$} & "A" & 0 & 0 & - & 0 & 0 & 0 & 0 & 0 & 0 & 0 & 0 & 0 & 0 & - & 0 & 0 & 0 & 0 & 0 & 0 \\
\hline & "B" & 0 & 0 & + & 0 & 0 & 0 & 0 & 0 & 0 & 0 & 0 & 0 & 0 & + & + & 0 & + & + & 0 & 0 \\
\hline \multirow{2}{*}{$\begin{array}{l}\text { Electricity } \\
\text { infrastructure }\end{array}$} & "A" & 0 & 0 & 0 & 0 & 0 & 0 & 0 & 0 & 0 & 0 & 0 & 0 & 0 & 0 & 0 & 0 & 0 & 0 & 0 & 0 \\
\hline & "B" & 0 & 0 & 0 & 0 & 0 & 0 & 0 & 0 & 0 & 0 & 0 & 0 & 0 & 0 & 0 & 0 & 0 & 0 & 0 & 0 \\
\hline \multirow[b]{2}{*}{ Telecommunications } & "A" & 0 & 0 & 0 & 0 & 0 & 0 & 0 & 0 & 0 & 0 & 0 & 0 & 0 & 0 & 0 & 0 & 0 & 0 & 0 & 0 \\
\hline & "B" & 0 & 0 & 0 & 0 & 0 & 0 & 0 & 0 & 0 & 0 & 0 & 0 & 0 & 0 & 0 & 0 & 0 & 0 & 0 & 0 \\
\hline \multirow{2}{*}{$\begin{array}{l}\text { Nature conservation } \\
\text { and reclamation }\end{array}$} & "A" & 0 & 0 & 0 & 0 & 0 & 0 & 0 & - & - & - & 0 & 0 & 0 & 0 & 0 & 0 & 0 & 0 & 0 & 0 \\
\hline & "B" & 0 & + & 0 & 0 & 0 & 0 & + & + & + & + & 0 & 0 & 0 & + & 0 & 0 & 0 & 0 & 0 & 0 \\
\hline \multirow{2}{*}{ Environment } & "A" & - & - & 0 & - & - & 0 & - & - & - & - & 0 & 0 & 0 & - & 0 & 0 & 0 & 0 & - & - \\
\hline & "B" & + & + & 0 & + & + & 0 & + & + & + & + & + & 0 & 0 & + & + & 0 & 0 & 0 & + & + \\
\hline \multirow{2}{*}{$\begin{array}{l}\text { Protection } \\
\text { Monuments } \\
\text { Culture }\end{array}$} & "A" & 0 & 0 & 0 & 0 & 0 & 0 & 0 & 0 & 0 & 0 & - & 0 & - & 0 & 0 & 0 & 0 & 0 & 0 & 0 \\
\hline & "B" & 0 & 0 & 0 & 0 & 0 & 0 & 0 & 0 & 0 & 0 & + & 0 & + & 0 & 0 & 0 & 0 & 0 & 0 & 0 \\
\hline
\end{tabular}

Based on the analysis of possible positive current trend continues for one can not and negative variations for individual sectors can be concluded the following. expect any positive effect, and adverse effects are present in half of the sector in

The development of alternatives to the relation to the objectives of the strategic 
impact assessment.

The options to propose a plan of eco plan for active and carry out measures for economic development, social welfare and environmental protection can be expected many positive effects in every sector, mitigate or compensate for most of the negative tendencies of development.

It is possible to generate the following key positive effects:

- reduce exposure to polluted air for people to establish protective forest belts and migration of population from the most vulnerable zones,
- reconstruction of existing facilities and building new hydro-technical structure will provide better water supply for the population and economy,

- through compensation and resettlement of the population achieved a favorable socio- economic effects and the conditions for the improvement of public health,

- relocation of cultural and sacred objects to preserve traditional values,

- economic development and increase employment,

- transport infrastructure, which is

Table 5.Summary of potential effects variant

\begin{tabular}{|c|c|c|c|}
\hline \multirow{2}{*}{ Sector } & \multirow{2}{*}{$\begin{array}{c}\text { Variety } \\
\text { Development }\end{array}$} & \multicolumn{2}{|c|}{ Effects of the goals } \\
\hline & & Negative & Positive \\
\hline \multirow{2}{*}{$\begin{array}{l}\text { Mining and economic } \\
\text { development }\end{array}$} & "A" & $1-5,7,10,15,19-20$ & - \\
\hline & "B" & $1,7,16-17$ & $3,8,11,18-20$ \\
\hline \multirow{2}{*}{$\begin{array}{c}\text { Population, public services and } \\
\text { housing }\end{array}$} & "A" & $1-3,5,7,16,19$ & 14 \\
\hline & "B" & 7,12 & $3,5,13-15,18-20$ \\
\hline \multirow{2}{*}{ Agriculture and forestry } & "A" & 3 & 7 \\
\hline & "B" & 7,9 & $2,3,8,10$ \\
\hline \multirow{2}{*}{ Traffic infrastructure } & "A" & 1,2 & - \\
\hline & "B" & 7,16 & $2,3,5,14$ \\
\hline \multirow{2}{*}{$\begin{array}{l}\text { Relocation of the river and } \\
\text { flood control }\end{array}$} & "A" & - & - \\
\hline & "B" & $3,7,10$ & $4,15,17$ \\
\hline \multirow{2}{*}{ Hydraulic infrastructure } & "A" & 3,14 & - \\
\hline & "B" & - & $3,14,15,17,18$ \\
\hline \multirow{2}{*}{ Electricity infrastructure } & "A" & - & - \\
\hline & "B" & - & - \\
\hline \multirow{2}{*}{ Telecommunications } & "A" & - & - \\
\hline & "B" & - & - \\
\hline \multirow{2}{*}{$\begin{array}{l}\text { Nature conservation and } \\
\text { reclamation }\end{array}$} & "A" & $8-10$ & - \\
\hline & "B" & - & $2,7-10,14$ \\
\hline \multirow{2}{*}{ Environmental protection } & "A" & $1,2,4,5,7-10,14,19,20$ & - \\
\hline & $\mathrm{B}^{\prime \prime}$ & - & $1,2,4,5,7-11,14,15,19,20$ \\
\hline \multirow{2}{*}{$\begin{array}{l}\text { Protection of Cultural } \\
\text { Monuments }\end{array}$} & "A" & 11,13 & - \\
\hline & "B" & - & $11-13$ \\
\hline
\end{tabular}


influenced by the development of mines will be relocated,

- implementation of the plan of environmental protection and monitoring program creates the conditions for establishing a coordinated system of environmental protection in the area.

In this variation can be expected and negative effects primarily under the influence of mining on air pollution, groundwater and surface water, the water supply system, changing land use, natural conditions, population, settlements and transport infrastructure.
2.2.9. Some characteristics of possible significant impact

The following analysis was performed to evaluate the size, spatial scale, the probability, duration and overall importance of the impact of the proposed (selected) variants, and those sectors in which they identified key influences, particularly negative on the environment. Estimates are included in decisions that are subject to the assessment of the impact on the environment.

Table 6.Assessing the size and spatial scale of environmental impact and the elements of sustainable development

\begin{tabular}{|c|c|c|c|c|c|c|c|c|c|c|c|c|c|c|c|c|c|c|c|c|c|}
\hline \multirow{2}{*}{\multicolumn{2}{|c|}{ Planned Solutions }} & \multicolumn{20}{|c|}{ The objectives of the strategic assessment } \\
\hline & & 1 & 2 & 3 & 4 & 5 & 6 & 7 & 8 & 9 & 10 & 11 & 12 & 13 & 14 & 15 & 16 & 17 & 18 & 19 & 20 \\
\hline \multicolumn{22}{|c|}{ Mining works } \\
\hline 1 & Takeover of land by 2010 . & $-2 \mathrm{~L}$ & $-2 L$ & $-1 \mathrm{~L}$ & $-1 \mathrm{~L}$ & $-1 \mathrm{P}$ & $-1 \mathrm{~L}$ & $-2 \mathrm{P}$ & $-1 \mathrm{P}$ & $-1 \mathrm{~L}$ & $-2 \mathrm{~L}$ & $-2 P$ & $-3 P$ & 0 & $-3 \mathrm{P}$ & $+2 \mathrm{P}$ & $-2 \mathrm{P}$ & $-3 \mathrm{P}$ & 0 & $+1 \mathrm{~L}$ & $+1 \mathrm{~L}$ \\
\hline 2 & Takeover of land by 2015 . & $-2 L$ & $-2 \mathrm{~L}$ & $-1 \mathrm{~L}$ & $-2 \mathrm{~L}$ & $-2 \mathrm{P}$ & $-2 \mathrm{P}$ & $-1 \mathrm{P}$ & 0 & $-1 \mathrm{~L}$ & $+2 \mathrm{~L}$ & $-1 \mathrm{P}$ & $-3 \mathrm{P}$ & 0 & $-3 \mathrm{P}$ & $+2 \mathrm{P}$ & 0 & 0 & 0 & $+1 \mathrm{~L}$ & $+1 \mathrm{~L}$ \\
\hline 3 & Takeover of land by 2020 . & $-2 \mathrm{~L}$ & $-2 \mathrm{~L}$ & $-1 \mathrm{~L}$ & $-2 L$ & $-2 \mathrm{P}$ & $-2 \mathrm{P}$ & 0 & 0 & $-1 \mathrm{~L}$ & $+2 \mathrm{~L}$ & 0 & $-2 \mathrm{P}$ & 0 & $-2 \mathrm{P}$ & $+2 \mathrm{P}$ & 0 & 0 & 0 & $+1 \mathrm{~L}$ & $+1 \mathrm{~L}$ \\
\hline \multicolumn{22}{|c|}{ Relocation of settlements } \\
\hline 4 & Moving from the zone box B / C" & 0 & $+2 \mathrm{~L}$ & 0 & 0 & 0 & 0 & 0 & 0 & 0 & 0 & 0 & $-3 \mathrm{P}$ & $+1 \mathrm{~L}$ & $-3 \mathrm{P}$ & 0 & 0 & 0 & 0 & 0 & 0 \\
\hline 5 & Moving from the zone field $\mathrm{E}$ & 0 & $+2 \mathrm{~L}$ & 0 & 0 & 0 & 0 & 0 & 0 & 0 & 0 & 0 & $-2 \mathrm{P}$ & $+1 \mathrm{~L}$ & $-2 \mathrm{P}$ & 0 & 0 & 0 & 0 & 0 & 0 \\
\hline 6 & Relocation of infrastructure corridors & 0 & 0 & 0 & 0 & 0 & 0 & 0 & 0 & 0 & 0 & 0 & $-3 \mathrm{P}$ & $+1 \mathrm{~L}$ & $-3 \mathrm{P}$ & 0 & 0 & 0 & 0 & 0 & 0 \\
\hline \multicolumn{22}{|c|}{ Waterpower engineering } \\
\hline 7 & Relocation of the river & 0 & 0 & $+1 \mathrm{R}$ & $+1 \mathrm{R}$ & $+2 \mathrm{P}$ & 0 & $-1 \mathrm{~L}$ & 0 & $+1 \mathrm{~L}$ & $+1 \mathrm{~L}$ & 0 & 0 & 0 & 0 & 0 & 0 & $+2 \mathrm{P}$ & 0 & 0 & 0 \\
\hline 9 & $\begin{array}{l}\text { Reconstruction of the network and } \\
\text { access to water system }\end{array}$ & 0 & 0 & $+2 \mathrm{P}$ & $+1 \mathrm{P}$ & $+1 \mathrm{P}$ & 0 & 0 & 0 & 0 & 0 & 0 & 0 & $+2 \mathrm{P}$ & 0 & 0 & 0 & $0 \mid+$ & $+3 \mathrm{P}$ & 0 & 0 \\
\hline \multicolumn{22}{|c|}{ Traffic } \\
\hline 9 & Relocation of road R-201 & 0 & $+1 \mathrm{~L}$ & 0 & 0 & 0 & 0 & $-1 \mathrm{P}$ & 0 & 0 & 0 & 0 & $-2 \mathrm{P}$ & 0 & $-2 \mathrm{P}$ & 0 & $+1 \mathrm{P}$ & 0 & 0 & 0 & 0 \\
\hline 10 & Relocation of the railway industry & 0 & $+2 \mathrm{~L}$ & 0 & 0 & 0 & 0 & $-1 \mathrm{P}$ & 0 & 0 & 0 & 0 & $-2 \mathrm{P}$ & 0 & $-2 \mathrm{P}$ & 0 & $+1 \mathrm{P}$ & 0 & 0 & 0 & 0 \\
\hline \multicolumn{22}{|c|}{ Reclamation and safety belts } \\
\hline 11 & Reclamation pits & 0 & $+2 \mathrm{P}$ & 0 & 0 & 0 & 0 & $+1 \mathrm{P}$ & $+1 \mathrm{P}$ & $+1 \mathrm{P}$ & $+2 \mathrm{P}$ & 0 & 0 & $+1 \mathrm{~L}$ & 0 & 0 & 0 & 0 & 0 & 0 & 0 \\
\hline 12 & Establishment of safety belt & 0 & $+2 \mathrm{P}$ & 0 & 0 & 0 & 0 & 0 & $+1 \mathrm{~L}$ & $+1 \mathrm{~L}$ & $+1 \mathrm{P}$ & 0 & 0 & $+2 \mathrm{P}$ & 0 & 0 & 0 & 0 & 0 & 0 & 0 \\
\hline
\end{tabular}


Table 7.Criteria for evaluating the size effect

\begin{tabular}{|c|c|c|}
\hline Size effect & Mark & The $\mathrm{p}$ ands \\
\hline Critical & -3 & Strong negative impact \\
\hline Larger & -2 & Greater negative impact \\
\hline Smaller & -1 & Minor negative impact \\
\hline No effect & 0 & No impact is not applicable \\
\hline Positive & +1 & Minor positive impact \\
\hline Favorable & +2 & Greater positive impact \\
\hline Very favorable & +3 & Strong positive impact \\
\hline
\end{tabular}

Table 8. Criteria for evaluating the impact of spatial scale

\begin{tabular}{|c|c|}
\hline The scale of impact & Mark \\
\hline Regional & $\mathrm{R}$ \\
\hline Area Plan & $\mathrm{P}$ \\
\hline Area Plan & $\mathrm{L}$ \\
\hline
\end{tabular}

\subsubsection{Analysis of effects cumulative an synergetic}

In the analysis include the assessment of cumulative and synergetic effects. These effects are partly identified, although significant effects may occur as a result of interactions between a number of smaller impacts of existing facilities and activities, and various planned activities in the area discussed, (Mihajlov, 2005).

Cumulative effects arise when the effects of more of the same individual effects accumulate, such as pollution of air, water or increase the level of noise from various sources.

Synergetic effects created in the interaction of individual impacts that produce the overall effect that is greater than the simple sum of individual impacts. Synergetic effects are usually manifested in human communities and natural habitats, (Radosavljević, et al., 2009).
For this plan are very important and indirect impact of the primary impact of the development of surface mines. The development of mines, in addition to the direct impact of the elements of the environment (land, water resources, air, ecosystems, health of the population), which require the relocation of settlements, roads and rivers, there are significant indirect effects that result from activities in the relocation, (Radosavljević, 2010). All effects together may have cumulative and synergetic effects:

- Air quality management: For mining the dominant dust emission during coal excavation and removal of overburden, which does not cause excess GVI on the surrounding neighborhoods. Bearing in mind that in the planning area is intense transport of coal (tape, trucks, railways) which is an important source of coal dust, possibly due to cumulative effects of excess GVI in unfavorable weather conditions. Positive cumulative effects to reduce exposure to polluted air, people realize and achieve the bottom of ways: (1) improving the monitoring system and (2) transfer of population from endangered areas.

- Water management: The proposed development of mining activities will inevitably affect the hydrogeological regime within the pits and cumulatively in the wider environment. Disturbance regime of water can have indirect effects on the modes of surface water, soil fertility and water supply of the population. Due to the development of mines will have to relocate parts of Pestana. It is possible to infiltration of pollutants in the pits and barren. Modernization of existing and construction of new water supply systems and povezivanjen the regional system will provide a stable supply of the population with drinking water. 
Relocation of vulnerable parts of the river flow regimes and improve the quality of surface water.

- Protection and use of land: In the period until 2020. The anticipated increase in surface mining and reducing the occupied area of agricultural land in the area of the plan. Relocation of the river to a certain extent, the favorable impact on the quality of agricultural land. The biggest contribution will be achieved by reclamation of degraded land.

- Preservation of natural resources, biodiversity and landscapes: Mining activity and strong land degradation and destruction of vegetation on the sites of some mines has cumulative effect on the loss of habitat of most animal species and cause them to move out beyond the zone of active mines.Relocation and improvement of river water flows will favorably affect the conservation of aquatic habitats. Total reclamation pits creating the conditions for renewal of habitats of flora and fauna, as well as to improve the characteristics of the area plan.

- Impacts of settlements and population: Cumulative negative impact on the number and structure of the population and characteristics of settlements due to the development of surface mines and the relocation of the current total of 1486 . and 2853. inhabitants. Small local impacts indicated solutions can become a significant cumulative with other sources of polluted air and noise (traffic, mining) within granciva plan.Planning solutions specified cumulatively contribute to the health of the population. On the one hand, reducing emissions, and the removal of population from other sources of contamination (transfer of population).

- Economic development area:
Cumulative interaction of planning solutions will significantly stimulate further economic development of the area and increase employment, not only in the mining sector, but also in other complementary activities.

- Relocation of roads and rivers: Cumulative mining activities in the mining will cause a strong impact and destruction of parts of roads and rivers. The above solutions will cumulatively contribute to the improvement of road network and the organization and regulation of rivers.

- System Environmental Management: In the development of environmental management authorities and stakeholders for the implementation of these solutions can be integrated to provide conditions for environmental protection in the area of the plan.

\section{PROPOSED MEASURES FOR REDUCING NEGATIVE IMPACT}

On the exploitation area in accordance with the completion of the survey, plans to continue the expansion of mining activities that previously confirmed cause numerous negative effects on all elements of the environment. For the realization of the concept of environmental protection in order to mitigate possible negative effects or prevent, it is necessary to take the technicaltechnological, organizational andplanning measures to protect the environment.

Investigated area is defined metrics to the level of vulnerability, environmental pollution can be divided into:

- the areas to be destroyed due to expansion of mining pits,

- zone, which can be compromised by excessive air pollution and noise, 
Table 9. Draft plan of environmental quality-ecological zoning of vulnerable areas

\begin{tabular}{|c|l|l|}
\hline $\begin{array}{l}\text { Category } \\
\text { pollution }\end{array}$ & \multicolumn{1}{|c|}{ Sites } & \multicolumn{1}{|c|}{ Description } \\
\hline I & $\begin{array}{l}\text { Surface coal } \\
\text { mines, } \\
\text { slag and ash } \\
\text { dumps }\end{array}$ & $\begin{array}{l}\text { Elevated concentrations of } \\
\text { dust,engine and exhaust noise }\end{array}$ \\
\hline II & $\begin{array}{l}\text { Coal transport } \\
\text { corridors }\end{array}$ & $\begin{array}{l}\text { Occasionally exceeding } \\
\text { permitted GVIprimary } \\
\text { pollutants, but without } \\
\text { excessive pollution, } \\
\text { radioactive, carcinogenic and } \\
\text { mutagenic substances }\end{array}$ \\
\hline III & $\begin{array}{l}\text { Corridor road } \\
\text { infrastructure and } \\
\text { railway }\end{array}$ & $\begin{array}{l}\text { Not expected to have } \\
\text { exceeded GVI, occasionally } \\
\text { increased dust and noise }\end{array}$ \\
\hline IV & $\begin{array}{l}\text { Eastern } \\
\text { andsouthernterritor } \\
\text { yof the impact of } \\
\text { mines }\end{array}$ & $\begin{array}{l}\text { Less pollution and at times } \\
\text { ming }\end{array}$ \\
\hline
\end{tabular}

Table 10. First defined the criteria for protection from noise

\begin{tabular}{|c|c|c|c|}
\hline \multirow[t]{2}{*}{ Zone } & \multirow[t]{2}{*}{$\begin{array}{c}\text { Description } \\
\text { of the acoustic zone }\end{array}$} & \multicolumn{2}{|c|}{$\begin{array}{l}\text { Permitted levels of } \\
\text { external noise Leq } \\
\text { (dBA) }\end{array}$} \\
\hline & & Day & Night \\
\hline I & Purely residential area & 55 & 45 \\
\hline III & $\begin{array}{l}\text { Along the main } \\
\text { and regional roads }\end{array}$ & 65 & 55 \\
\hline
\end{tabular}

- zone where no expected excess of GVI,and

- the areas in which occurs occasionally or less pollution.

\subsection{Proposed environmental priorities}

From the aspect of protection of all elements of the environment and human health, it is necessary to implement priroritetne following activities:
1. In the preparatory phase for the extraction of coal:

- form a protective belt of greenery (imisionih protective forests) priority in urban zone.

2. In the stage of coal:

- introduce a system for spraying the coal mining and transportationtrucks and conveyor belts,

- cap presipa of coal,

- provide selective overburden disposal,

- organize monitoring of air quality, water and soilin the vicinity of mines in the direction of potentially vulnerable parts of the settlement.

Air pollution in the planning area is caused by emissions from surface mines (due to the extraction of coal, waste disposal, operation of mining machinery), from transport (transport of coal strip, truck and rail) and during winter from individual furnaces, (Radosavljević, 2010). To reduce the level of emissions into the air and reduce the degree of exposure to polluted air of the population, it is necessary to implement the following measures:

- the active part of mine (during excavation of coal) and coal dumps provide treatment for the prevention of air spraying dust,

- build a protective green belt around the pits (minimum of 200 feet, spreading to areas that are oriented towards the settlements - a minimum of $300 \mathrm{~m}$ ) before starting the operation,

- cap of coal presipa prekrivke placing metal and rubber sealing open space moving parts pertaining to prevent dust,

- embed "Mini Jet" systems for the transportation of coal wetting,

- use machinery with reduced emissions, 
- $\quad$ in zone II time line R 201 (a large ecological zone load) in width by $20 \mathrm{~m}$ on either side of the road, allowed the construction of facilities in the function of time and the formation of protective vegetation. Not allowed to build residential, commercial, and auxiliary facilities,

- organize monitoring the concentration of dust in the working environment of surface mines and in residential areas near the mines,

- $\quad$ establish a system of monitoring air quality in accordance with the European directive on the assessment and management of ambient air quality and households that are directly threatened by the development of open pits and activities in the areas of transportation of coal, and move them in an environmentally safe location.

To ensure sustainable use of water, preserve groundwater regime and surface water and improve the quality of groundwater and surface water is necessary to:

- restore and improve systems and channeling waste water,

- $\quad$ organize the monitoring and control of waste water from mines,

- establish a system of monitoring water quality,

- $\quad$ system monitoring groundwater and surface water supplemented with measuring points that are sensitive from the point source water pollution,

- establish an automated system to monitor and control the level of groundwater and surface water in the area of mines in the area of the negative effects of lowering levels of groundwater in the zone of influence mines,

- determine the immediate protection zone around the wells for water supply in the width of10 $\mathrm{m}$ where they are not allowed any activities that are not in the function of water supply, and the inner zone of protection at a distance roughly the potential hydraulic impact on the quality of underground water sources in the zone,

- implement a sewage system, the separation system for environmental burden of settlement.

To prevent damage to buildings and infrastructure around mines due to lowering of groundwater levels and ground subsidence is necessary to:

- $\quad$ prior to construction of infrastructure facilities, to do a study with a detailed analysis of conditions beginning skating terrain and provide solutions for remediation of landslides,

- do plan monitoring the stability of land and buildings in the zones front advancement mines,

- establish a surveillance system for subsidence/movement of soil by placing points and benchmarks trigonometric network for surveillance of the wider area, and adequately respond in case of damage to the appearance of individual buildings.

Development of open pit occurs destruction and degradation of significant areas of agricultural and forest land, degradation of landscapes and endangering the wild flora and fauna. In order to minimize these impacts or compensate for it is necessary to:

- prior to mining waste disposal to provide selective overburden,

- $\quad$ successive reclamation of land after the mining,

- consistent with the pace of mining works,

- recultivation plan so that it more closely matches their natural state and create conditions for the restoration of fauna,

- develop a registry of biological 
species diversity areas, as a basis for biological reclamation projects of degraded areas and watercourses,

- establish monitoring the quality of land near the mines.

Mining and related activities, together with the traffic are the main sources of noise on eksplotaconom area. To reduce the noise impact should be provided with protective distance and technical solutions to meet the criteria of the applicable standards. In addition naavedenog needed:

- build a protective green belt around the pits (minimum of 200 feet, spreading to areas that are oriented towards the settlements - a minimum of 300 feet) before the start of exploitation,

- $\quad$ in zone II with state time line R 201 (a large ecological zone load) in width by 20 $\mathrm{m}$ on either side of the road, allowed the construction of facilities in the function of time (gas stations, services, warehouses, etc.), and the formation of protective vegetation. It is not allowed to build residential, commercial and auxiliary facilities. Households that are directly threatened by the development of open pits and activities in the area of transportation of coal to move in an environmentally safer location.

In accordance with the results of research, monitoring system and quality management of the environment is not sufficiently developed, given the intensity of the impact caused by mining and other activities in the exploitation area. In this context it is necessary:

- enhance the professional management of the environment in mining and local government,

- an operational plan to do the monitoring of air, water and soil,

- introduce a system of environmental management complies with applicable standards,

- plan to do environmental protection, including a plan to respond to incidents and episodic environmental pollution,

- establish an information system environment, which in addition to the results of local monitoring system keeps track of data and the sources of local and national relevant institutions (the cadastre of the environment),

- provide public information on environmental problems in the exploitation area,

- ensure public participation in making decisions about solving environmental problems, including all potentially affected and interested parties.

\section{ABILITY TO MANAGE ENVIRONMENTAL RISKS}

Environmental risk management involves responding to identified risks and includes formulating and implementing policies to reduce social risks specific environmental hazards. It is a process of choice between alternative regulatory and neregulativnih instruments for responding to environmental risk, (Radosavljević, S. \& Radosavljević, M., 2009).

Environmental risk management include: determining rihvatljivog level of risk and environmental assessment and selection of risk management strategies. Determination rihvatljivog level means the level of risk that is necessary from the perspective of some other areas. This level is low but not zero. Evaluation and selection of risk management strategies include the following strategies: comparative ecological risk of analysis, risk analysis and use, analysis of benefits and 
costs, (Radosavljević, S. \& Radosavljević, process model to analyze and reduce echo. M., 2009). Comparative risk of analysis can Here are four steps defined in the analysis of help in the selection of najpodesnijeg environmental risks particularly emphasized alternative instrument for effective risk the function of the expert module eco / eco reduction. Risk analysis also considers the level of risk associated with environmental risk and benefits to society from regulation given environmental hazards. Cost-benefit analysis is a method of economic analysis which upoređujui evaluate all the advantages and disadvantages of all a commercial enterprise or project cost analysis (cost) and benefit (benefit). Cost-benefit analysis compares the usefulness of cross-border social policies to reduce pollution related border costs. Efficient level of environmental risk is one in which the limit is equal to limit the social utility of social costs.

team in the context of its operationalization. Each step is important, but third and 4 is a particular problem for environmental risk analysts. It should adopt a methodology and apply an appropriate model for analysis. Application of matrix-type model is always a risk analyst leaves room for some independent decision-making, (EN 1050 :1996). The same can often are compared.

If it is a part of the analysis relating to the technical aspect that causes environmental criticality, which was the aim of the research subject, often in the application: (EA-Energy Analysis), (HAZOP-Hazard and operability In Figure 1, provides an overview of the Studies), (FTA-Fault Tree Analysis), (ETA-

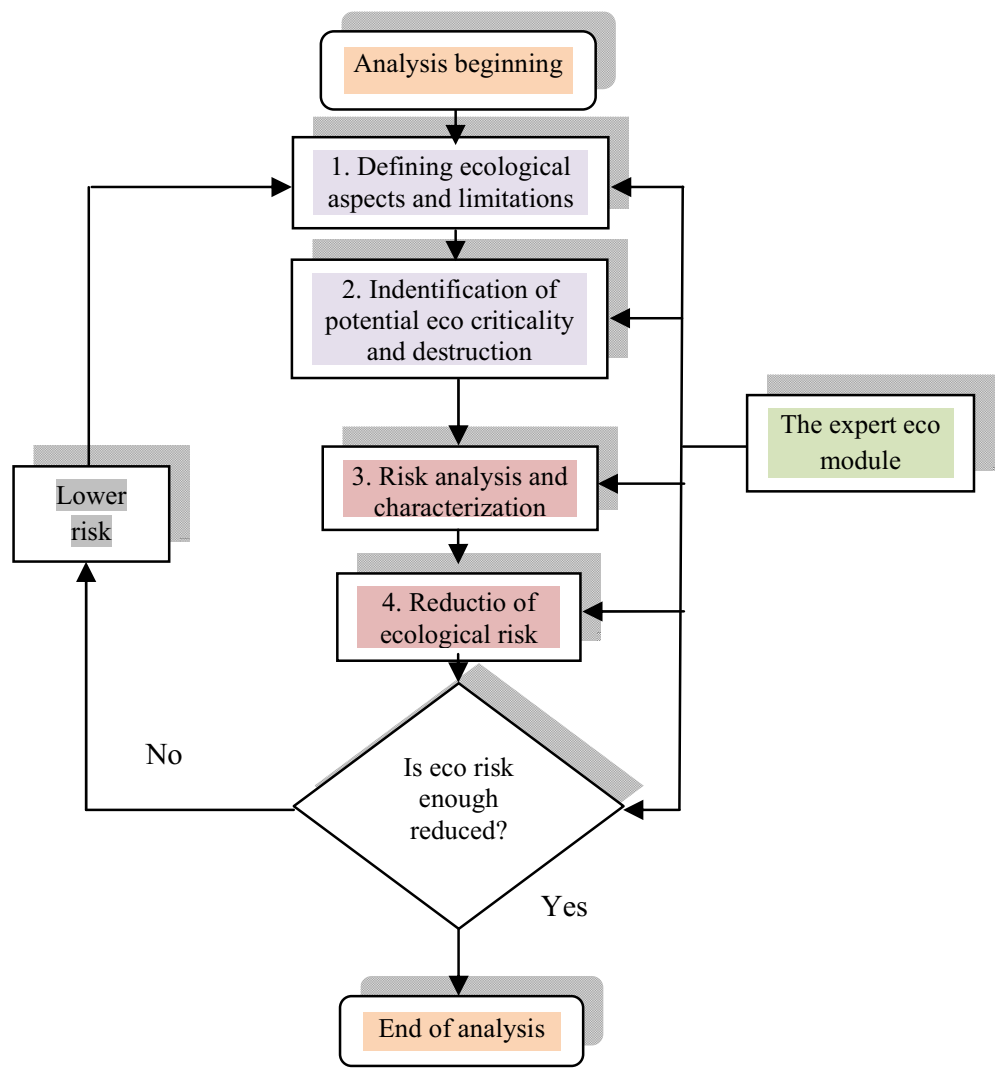

Figure 1.Overview of process models for analysis and reduction of environmental risk, (Adapted by $A A E, A A N$ and $E N$ 1050) 
be subjective depending on the technical and practical competence by analysis, (ISO 31000, (2009). When found in the dilemma as to what position a potential objective criticism, it is always better to assign it a higher risk index (higher threshold range), due to possible personality would not significantly influence the output results of the analysis, (Radosavljević, S. \& Radosavljević, M., 2009).

Often there is a need to de composed environmental aspect analysis on several grounds and criteria. We can choose several models for the analysis and the results Event Tree Analysis), Designsafe 5.0., (Radosavljević, S. \& Radosavljević, M., 2009).

The most frequently used methods for risk assessment of work activities of people are: (Human Error Analysis), (Human Reliability Assessment-HRA), (THERP-Technique for Human Error Rate), (CREAM-Cognitive realibility and Error Analysis Method), (Hierarchical Task Analysis ) (JSACognitive Task Analysis), (Job Safety Analysis). The most frequently used methods for the analysis of accidents are: (Change Analysis), (Deviation Analysis) and (Safety Function Analysis), (Radosavljević, S. \& Radosavljević, M., 2008).
The proposal of a functional organizational model for management of the environment implies the existence of a separate sector with expert multidisciplinary team of experimental research and generating solutions and continuous improvement. In the same recognized the need to analyze, categorize and reduce environmental risks.

Qualitative environmental strategy is the basis for making short-or medium-term environmental plan. In accordance with the identified criticality, environmental destruction and potential risks pozicionoranjem proposed response to the same, followed by generation of high-quality environmental programs and projects to their practical implementation.

Quality control and environmental monitoring lead to constant improvements that would be constantly preispitivala a redesigned eco-system. There is a possibility for the development of eco-catalog database as the risk thresholds for eco-criticism and the potential environmental destruction. They would be part of a broader eco-system of cataloging for the near and surrounding areas for further exploitation, (Radosavljević, 2007).

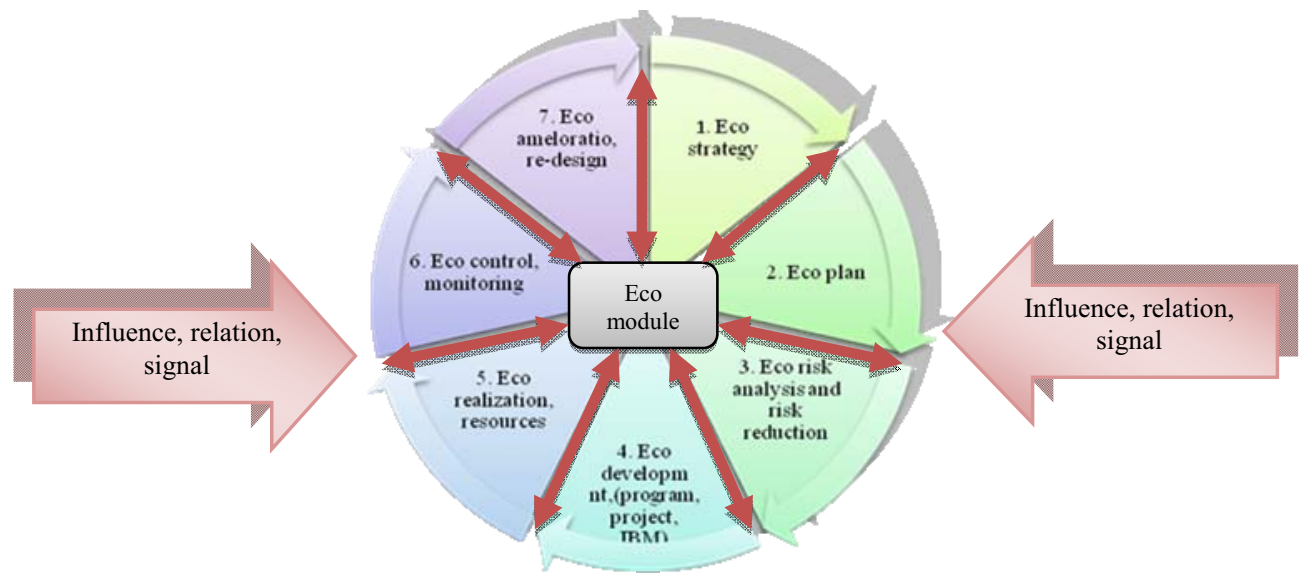

Figure 2.Proposal organizational functional modules of environmental protection 


\section{DISCUSSION OF RESEARCH RESULTS AND PROPOSALS PRESENTED}

Results of completed studies have demonstrated the complexity and structural complexity of the macro-and micro-sites surrounding the exploitation of resources with environmental aspektnog approach. Detected a number of eco weakness, which is measured through various destructive applications and can cause long term and specific incidents of eco supozicije and situations. Influences are diverse, variable in many lokalitetnih areas and is especially indicative of the population of the population, that is just being there with his household is located.

Adapted process model for the analysis and reduction of environmental risks can actually establish a qualitative and integrative approach primarily in that context. Positioned provide methodological sledljvost steps in the analysis of environmental risks at the same time establish the need for real high threshold of competence to access multi-disciplinary framework, which directly affects the final output results of the analysis.

Eco-type matrix models and you can be too demanding for risk analysts, actually always simple and the target set for the adoption of wide area environmental constructive not decisions that can ultimately affect the final results, form, shape, and the validity of the presented results.

The proposal of a functional organizational model for environmental management in the area of macro-and microexploitation of resources, says the new configuration of multi-disciplinary environmental and methodological approaches, which up to now based on the results of the research is definitely not established or maintained. Without these particular can be difficult to generate and establish the initial potential for a high quality ecoresearch site and maintain the same with constant monitoring and continuous environmental improvement.

\section{CONCLUSION}

Locality exploitation in the region must ensure that the parameters of air quality, water and land meet the requirements of reference, first agreed to the demands of the European Union. Without proper consideration of the strategies of solving the existing environmental problems with the analysis of environmental risks and constant environmental monitoring, it is not possible to achieve development and prosperity in the areas affected by exploitation works.

The action plan presented in this paper contains about thirty activities with partial coverage of technical and technological measures, which would mainly be to plan for pollutants in order to minimize contamination. Exploration of the environment, points to the need for monitoring and control: the quality of ecosystems, the effects of noise and heat, all materials that enter and leave the production of industrial processes and key parameters of the production process. The fact is that most businesses are not carried out systematic measurements of emissions and imission, monitoring of waste water and soil pollution monitoring. Knowledge in the field of environmental protection, provide quality opportunities for overall improvement.

Analytics and methodological research sites exploitation process shows that it is possible and necessary environmental 
improvements in production practices mining. The presented results of the analysis indicate that the systemic approach can affect the overall reduction potential of eco-criticism and destruction and with the proper metrics and control as well as constant monitoring, provide real satisfactory and acceptable ecological condition.

The paper also provides a possible approach to environmental management at the site affected by mining. Problem analysis, karaterizacije, especially the reduction of environmental risk in this context is really great and requires new approaches or redesign existing ones.

Relevant research has shown that the analysis of environmental risk is almost nonexistent or at the very beginning of the scientific, professional, and especially practical operacionalizovanja. Experiences from the environment further suggests that no results in this area, it is very difficult to generate qualitative environmental progress at the macro-and micro-site environment. The proposed functional organizational model, can serve as a basis for creating the initial experience to a new focus in the analysis of environmental risks. The real problem may be the absence of competent analysts environmental risk (in the presented research in this area is covered by the author). Future time decides the real focus in the scientific and professional obligations of the public to question the analysis, characterization and reduction of environmental risks, as well as the structural foundation of practical eco-system eco-living and working on environmental protection. With all this to include new educational approaches and application of modern scientific methods and models.

\title{
УПРАВЉАЊЕ ЕКОЛОШКИМ РИЗИКОМ У РУДАРСТВУ, ЕКО-ПРАКТИКУМ
}

\author{
Слободан Радосављевић ${ }^{\text {* }}$ и Милан Радосављевић \\ $a_{Р Б}$ "Колубара", Лазареваи, Светог Саве 1, Лазареваи, Србија

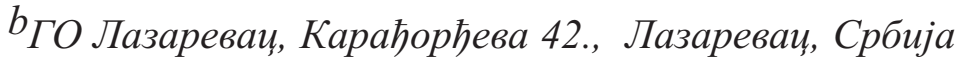

\section{Извод}

Заштита животне средине представља кључни фактор одрживог развоја на подручју експлоатације природних енергетских ресурса. Решавање проблема у овој области захтева квалитетно стратешко еко позиционирање експлоатационог локалитета, које је и највише оптерећено еко проблемима, засновано на савременим научним приступима и одређењима. Реално су честе еко критичности и опасности у рударству у потенцијалима различитих исказа. Присутно је дугогодишње нарушавање природних токова и укупне еко равнотеже система. Испољене деструкције и еко штете мањих или већих обима су последица, којима се приступа са аспекта предузимања корективних мера по стању. О комплекснијој анализи узрока, анализи еко ризика и дефинисању превентивне еко стратегије, тешко да се може и говорити, бар у формама савремених аналитичких и методолошких приступа. Основ одређења је у иницирању заинтересованости о преузимању одговорности за локалне еко приоритете и њихову заштиту у зонама интезивних експлоатационих радова. У питању је негативан утицај на здравље људи и потреба за очување укупног еко система. Анализа еко ризика постаје логистички циљ и потреба са којом се мора флексибилно, адаптибилно и квалитетно уредити приступ и управљање еко стварношћу и истином у контексту побољшања, сада и у ближој будућности. У раду се презентирају реална истраживачка искустава и резултати еко практикума у предлозима и примени савремених концепција, метода и модела за анализу еко ризика.

Кључне речи: еко ризик, еко практикум, еко деструкције, модел, рударство 


\section{References}

Asif, M., Bruijn, E., Fisscher, O., Searcy, C. \& Steenhuis, H. (2009). Process embedded designof integrated management systems. International Journal of Quality \& ReliabilityManagement, 26(3): 261-282.

Afrazeh, A. \& Bartsch, H. (2007). Human Reliability and Flight Safety. International Journal of Reliability, Quality and Safety Engineering, 14(5): 501-516.

Bernardo, M., Casadesus, M., Karapetrovic, S. \& Heras, I. (2009). How integrated are nenvironmental, quality and other standardized management systems? An empirical study. Journal of Cleaner Production, 17(8): 742-750.

Bernardo, M., Casadesus, M., Karapetrovic, S. \& Heras, I. (2010). An empirical study on theintegration of management system audits. Journal of Cleaner Production, 18(5): 486-495.

Griffith, A. \& Bhutto, K. (2008). Improving environmental performance through integratedmanagement systems (IMS) in the UK, Management of Environmental Quality. An International Journal, 19(5): 565-578.

Dependability management-Part 3 . (1995), Application guide-section 9: Risk analysis og technological systems, 12, (3.5), pp. 15.

Dhillon, B.S. (2005). Reliability, Quality and Safety for Engineers, SRC Press, Boca Raton, pp. 237.

EN 1050:, (1996). Principles of risk assessment is the Harmonised European Standard that specifies the risk assessment for machinery. www.riskman.info/en.

Law on the Protection of Environment, S1. Herald RS, number 135/04, Beograd, (2004).

IS CEI 300-3-9. Part 3. Dependability management-Application guide-Section 9:
Risk analysis of technological systems, 1995-12, (1995), 36-38.

ISO 31000, (2009). Risk management principles and guidelines, (Pages: 3-22, of 24), (2009-11-13), ICS: 03.100.01, (International Organization for Standardization).

Karapetrovic, S. (2002). On the concept of a universal audit of quality and environmental management systems. Corporate Social Responsibility and Environmental Management, 9(3): 147-156.

Karapetrovic, S. \& Casadesús, M. (2009). Implementing environmental with other standardized management systems: Scope, sequence, time and integration. Journal of Cleaner Production, 17(5): 533-540.

Environmental quality of the city of Belgrade in 2005. year, the City of Belgrade Secretariat for Environmental Protection, GZZZ., REC. (2005), 31-43.

Main, W. B. (2005). Risk Assessment: Basics and Benchmarks, Design safety engineering, inc, ann Arbor, Michigan, 2123.

Michael, J. B. \& Launa, G.M.(2003). Focus on Prevention: Conducting a Hazard Risk Assessment, Centers for Disease Control and Prevention, National Institute for Occupational Safety and Health Pittsburgh Researc Laboratory, Pittsburgh, 35.

Mihajlov, N. A. (2005). Sustainable Development and Environment for Europeand 95+ steps-, Beograd, 31-43.

Mihajlović, I., Nikolić, Đ., Štrbac, N., Živković, Ž. (2010). Statistical modelling in ecological management using the artificial neural networks (ANNs). Serbian Journal of Management, 5(1): 39-50.

Report of the World Bank-Serbia and Montenegro, Review of environmental sector, the Ministry for the protection of 
natural resources and environment, Beograd, (2003).

Radosavljević, S., Lilić, N., Ćurčić, S. \& Radosavljević, M. (2009). Risk Assessment and Managing Technical Systems in case of Mining Industry. Strojniški vestnik-Journal of Mechanical Engineering, 55(2): 119-130.

Radosavljević, S., (2010). Technical Diagnostics Systems and Risk Analysis in Mining, VIII International Symposium, Mechanization And Automation In Mining And Energy, MAREN 2010, Lazarevac, 158161.

Radosavljević, S. (2010). Risk evaluation model of work safety process in the section dry separation, Kolubara Prerada, Vreoci, Doctoral dissertation, Faculty of Mining and Geology, Belgrade, 81-95.

Radosavljević, S. \& Radosavljević, M. (2009). Risk Assessment in Mining Inustry: Apply Management. Serbian Journal of Management, 14(1): 91-104.

Radosavljević, S. \& Radosavljević, M. (2009). Contemporary models for risk analysis in mining Serbia. Tehnička dijagnostika, 1: 17-24.

Radosavljević, S. \& Radosavljević, M. (2009). Risk technical systems: model and sotware Designsafe 5.0. International Journal of Software Systems and Tools, 1(1): 45-53.

Radosavljević, S. \& Radosavljević, M. (2008). Hazop Analysis Of MiningManagement Application. Tehnička dijagnostika, 7(2): 25-32.

Radosavljević, S. (2007). Risk management in mining. Scientific And Technical Journal For Quality Improvement, ISSN 0354-2408, Quality, Poslovna politika, Beograd, 7-8: 68-72. 